\title{
Intellectual and Literary Tendencies of Children Poems in Iran
}

\author{
Tahereh Taghavi Shavazi \\ Broadcasting Organization of Yazd, Iran \\ Ali Edalati \\ (Correspondent Author) \\ Department of Social Science, Payame Noor University, Iran \\ Email: alisq2008@yahoo.com \\ Zainab Ghadar Band Shirazifard \\ Department of Social Science, Payame Noor University, Iran
}

Accepted: August 17, 2012 Published: September 21, 2012

Doi:10.5296/jsr.v3i2.2428 URL: http://dx.doi.org/10.5296/jsr.v3i2.2428

\begin{abstract}
In the article, it was tried to consider intellectual and literary tendencies of children poems in Iran by analyzing the contents and some children poems as well. Different periods of Iranian literary history on children literature have been investigated in the study. As in the world, for wars and diseases, Iran has also a history full of ups and downs which has appeared in the poems composed by children poets and in the study, it has been tried to analyze the appearances. Undoubtedly, poems have a deep and constructive effect on a human life whether a child or an adult. A poet composes, in his or her poem, feelings and needs such as sadness, happiness, fear, hope, and all good and bad effects in the life. And, the children poets compose their own desires for the children who once will make society adults. From the beginning of composing poems for children, purposes of the poets have been either to educate them or they wanted to impose their own social and political purposes in poems to children; and each of them has composed his/her poems in a national, religious national or religious space. In compositions whose origins are sometimes the national belief, the Iranian children poet employs national myths, heroes, ancient and mythological stories, mostly Iranian characters in Persian literature masterpiece, Shahnameh, in his/her poem. And sometimes, national and religious beliefs are both themes of Iranian children poems.
\end{abstract}

Keywords: Children Poem, National Tendency, Religious, Religious National, Classic, Modern Classic.

\section{Introduction}


It is not simple to compose poems for children. To know children delicate and colorful world, desires and imaginations and to use lexicons and language proper to them is delicate and complicated. From old days, too much attention has been paid to the children in the old Iranian legends and tale. This shows importance of the children and offspring in Iranian culture. After the Iranian got familiar with principles of Islam and its attentions to educations and great men such as Imam Mohammad Ghazali (450-505 A.H.) and Ibne Hazm Andelosi (deceased in 456 A.H.) considered educations and focused on necessity of poems memorizations by children, their emotional needs were considered and some poems, although brief, were composed for children, with themes of advices, among of what were composed for adults. Nezami Ganjavi, Mowlana Jami and Masoud Sa'd Salman are among of such poets. It is not so long since when children poems have appeared systematically in Iran. The researchers have known the Constitutional era as beginning of social revolutions and a time when children literature was paid attention although advices are an integral part of most poems at all times. In constitutional era, the poets tried to compose poems for children and composed good poems. And, there are still poets who are composing poems for children; and to consider children emotions has turned into one of their concerns. In the meantime, each poet has composed and is composing poems for children according to his/her own intellectual and literary tendencies.

\section{Intellectual Tendencies}

\subsection{National Tendencies}

Homeland and nationalism sometimes become one of the most important concerns of a poet, even of a children poet, in a part of children literature history; and the children poet tries to use national and mythical figures in his/her poems and even to state of patriotism. Sense of nationalism in Iranian children poems may be known as a kind of homeland Romanticism which is always considered through children songs and poems, and sometimes in explicit slogans; however, its frequency swings in regards with social crises and variety of children poets. This nationalistic or patriotic thought in children poems is usually shown through a child's feelings towards "fatherland" and "praise to its unique beauties". (Salajegheh, 2008:469-470):

Beautiful autumn,

Full of colors

Lessons by teachers,

Sweet and Sweet

A lesson from jungle

A Word from desert

And a beautiful poem

From our homeland

And such a land is

What I love 


\section{Il Macrothink}

Blue and blue,

I pass through

The streams,

The seas,

Be eternal,

Beautiful Iran

(Rahmani, 1994: 10)

Green, white and red

Are colors of our flag

Flag of our country,

How beautiful it is

(Ghasemnia, 2001: 2)

And:

The moth was laughing,

The spring was laughing

Brought a happy news

The moth through flowers

Said dear Iran

Is a prosperous land

A homeland forever

A free safe place...

Give a laugh, babies

To keep happiness alive

With such a happiness

Make the city prosperous

Be joyful, babies

To keep Iran laughing

To make Iran eternal

(Tayefi, 1997: 3)

In all societies, national patriotic anthems are common among children. Years before and after Iranian revolution, such anthems have been and are commonly used. Even in constitutional era (August 6,1906), such patriotic feelings extremely aroused and appeared in poems and influenced the poems for children of that time as well. After constitutional era, homeland entered rational field of intellectuals like many other new social concepts although "in anthems of most poets in and after constitutional era, homeland got specified geographical borders and patriotism was in a closed circulation". (Sangari, 2003: 108). In a poem for children under title "Rulers \& the People", Ali Akbar Dehkhoda (1906) says his readers of homeland plundering by foreigners, in a conversation between a mother and her child. In this poem, the "goat" is a symbol for homeland and the "wolf" is a symbol for enemies.

Don't cry; bogy comes and eats 
The wolf comes and takes the goat

O... O... mommy... what's wrong? I'm hungry

Burst... you ate a lot; is it low?...

(Dehkhoda, 1982: 4)

In another poem, Dehkhoda reminds respects to the homeland by a memory from his own childhood:

Still I can remember, in childhood

I once touched poultry nest

He hit me so hard that

My tears spurted like blood

Father laughed at my cry and said

Learn patriotism from the poultry

(Dehkhoda, 1982: 125).

\section{Epic and Poems for Children}

"Epic in one of the literary devices and the stories in poems or epic verses describing athletics, braveries, and honors by races and nations" (Masaheb, 2001: 864). The epics usually originate from old mythical, athletic and historical stories and sometimes imaginations forms their origins (Makareiminia, 2004: 13). Among of epic verses is Shahnameh Ferdowsi (940-1018 A.D.) which is actually a story of a nation during centuries and a diagram of their culture, thoughts and ideals. The children always showed interests to epics, especially verse epics, including the masterpiece of Ferdowsi, Shahnameh. Demon, heroes and mythical figures in national epics, who are unique to power, have encouraged the children to hear the epics. Meanwhile, poems in epics are simple and fluent, and they are not difficult for children to understand. From when we can say poems were specifically composed for the children, the children poets have tried to use mythical and ethnical characters in their poems to express his/her own views, considering enthusiasm of children to hear such rhymed stories.

Archer Arash verses which have come in children literature mostly for its justifiability, try to consolidate an eternal epic and this depends on dialogs to be connected between that generation and one at the present and in the future. However, what is obvious are these verses, with all strong and weak points, have been composed in a specific part of Iranian social lives and formed a meaningful conversation with the addressee in that time (Salajegheh, 2007: 489). In this poem, describing snowfall in the beginning, which is a fall without any beginning and ending, and tradition of storytelling beside fire flames like narrating old epics, Arash's boasting and his unidentified body which connect his character to the myth, all are in an epic space full of national feelings (Salajegheh, 2007: 489). And here is a part of the poem by Archer Arash:

Snow falls 


\section{Al Macrothink}

Snow falls on thorns and rocks

Mountains, silent

Valleys, nostalgic

Routes, looking forward to a caravan with bell rings

If no smokes were on roofs of cottages

Or a light flicker did not have any message

And, if footprints weren't left on routes

What would we do in cold blizzard?

There, is a light cottage

On the hill, in front of me

Door opened

I was treated kindly

Understood, far from story of snow and cold rages

Beside fire flames

Uncle Nowrouz tells stories for children...

Life needs flames, cried uncle Nowrouz

Firewood should keep the fire blazing

My children! Our story is of Arash

He was like a garden of fire

It was a time

Hard and rough

Our fortune's dark as the malevolent faces

Enemies dominant over our lives

Slapped city had delusions

It had depressing stories to be narrated

Life dark and cold as a rock

Day of stigma

Time of scandal

Zeal winding in bondage ties

And love breathless for dejection disease

(Kasraei, 2008: 101 - 105).

\section{Religious Tendency}

However national and mythical aspects were considered in composing poems for children in a period of time and religious matters were found less, a significant growth of religion can be seen in another period. Although religious literature has been defined in various forms and any one has been involved with his/her tendency, it can be generally said that "religious literature of children is attributed to any great work in which imagination is involved and, in addition, connected meaningfully to real world of children and their emotional cognitive features and makes such matters related to religions realized by children (Daneshmand, 2000: 79). One of the major axes in developing specific thoughts in Iranian children poems is thoughts on ideological belief and, especially, on religion. For lower age groups, the thoughts 
are employed in a simpler form (Salajegheh, 2008: 408). Although such poems, which enjoy religious appearance, seem to be clichés, the themes of the following poem are theology and religious worldview:

Dawn courier's come

Knocking the door

In morning, removes dark clothes

From night body

Izan is heard

From mosque domes

It's time to pray

Green time of pray

Open the lips

And thank God

Say in a whisper

No god exists save Him

(Dehghan Azad, 1998: 9).

And:

Prays, morning and light have decreased

Go towards prayer rug

But take some roses

For whines and moans

(Nazar Arahi, 1997: 9).

\section{Religious National Tendency}

Although religious poets, especially on theology, were composed before Islamic revolution, the children poets tended more to the poems with religious themes after the revolution as well; especially the themes of children poets were on jihad, martyrdom, sacrifices and braveries in early years of the revolution (1978) and war time. The poets mostly tried to consider national, athletic symbols and even new athletic myths in such poems, especially those which described braveries, jihad and martyrdoms of soldiers, in addition of mentioning religious figures such as Islam prophet, Mohammad (p.b.u.h), Imams and showing the ways of their lives. National symbols are those which are "to express patriotic feelings and to praise motherland in poems and are interpreted in such a scope" (Salajegheh, 2008: 200-201). In the following poem, the poet employs athletic symbols of "Rostam, Sohrab, Esfandiar" to tell children of a father braveries who goes to war to defend his country and is killed finally for the purpose:

I'll write a story

Of strange heroes in twilight moments

Of tire narrator's voice

Of silence of decent narrators

Once again, I'll describe 


\section{Macrothink

Moments of anxiety and waiting

Will be back Rostam from the war

Left in battlefield corpse of Esfandiar

I'll write a story

A story from sorrows of a hero

It will burst into tears

In the story climax

I'll write more and more

My hero will break

Rostam agonizing of sorrows

Hero Sohrab left falling on ground

I'll write a story

A story from dad going to war

I remember the day he went

He had a rifle on his shoulder

Mother feeling nostalgic

Sky of our alley started raining

He smiled at me while leaving

On his head, mother kept Koran

Dad went in a hurry

From him, we received a letter

I saw a pigeon flied

From our pigeon house

I'll write a story

A story from dad's picture in photo frame

Of decent heroes in twilight moments

Of pleasant sun rising

(Ahmadi, 1997: 15).

\section{Literary Tendencies}

When poem language came close to street talks, poems for children were composed as well; and it is the constitutional era. Therefore, the literary tendencies of poets who have been considered as children poets after constitutional era will be studied in this part. Considering the works remained from constitutional era, most poets of the time composed classic poems; but it does not mean that the poet is full of difficult vocabularies and expressions. In fact, it was simplicity, fluency, and abundance of slang terms in such poems which made them beautiful and pleasant for children. It is after Nima and his insistence on composing free poetry when the poets joint to two hostile groups. On one hand, there were conservatives who did not want to break the limitations and violate old literary traditions and on the other, there were revolutionaries or the newfangled who were interested in a change in old Persian literature (Arianpour, 2008: 572). And, it is the difference in taste which encourages Poet Laureate Bahar (1886-1951) to say in the first congress of Iranian writers: "we are now 
standing at a crossroad in the history; a way to obsolescence and stop, and a way to novelty and moves. Any writer who directs the people to the future and life movement and wears robe of reality and compassion, his commodities will be more desirable and more common (the same: 481). Basically, there are two main and known definitions for poets in our past literary tradition; one originated from traditional theorist's views on top who is Shams Qeis Razi and the other related to philosophy which considers the poets and the contents on Aristotle's philosophy and his poetical style on top who is Ibn Sina (980-1307) and Khajej Nasir Al-Din Toosi (1216-1274) already contemporary with Shams Qeis, which has been delicately considered in Asas Al-Eghtebas (Poornamdarian, 1998: 195). Shams Qeis emphasizes on rhymes and rhythms, and Khajeh Nasir on imaginations; however, both called the words poems which had rhymes and rhythms (the same: 195-196). In the beginning of composing poems for children, constitutional era, those who considered the children as their main addressees and even those who composed childish poems with political themes to stay safe from power brokers' harassments, both believed in traditional style but different from the past. Dr. Shafiei Kadkani, on Persian poems periods, says: Constitutional form more or less is far from consolidated classic forms (Shafiei Kadkani, 2001: 41). All Iranian people, since long time ago, have deal with Persian poems anyway; the poems whose beauty and system were ingrained by all and were assumed so eternal and unchanging that no one thought they could be manipulated, even when Iran was basically changing (Shams Langaroodi, 1998: 35) but, intentionally or inadvertently, literature including poems got a new form and it was an introduction to literature revolution in next periods. This period was a subject for revolution literature but the literature, itself, was not the subject of the revolution. That is, a special literature appeared in the revolution but no special revolution appeared in the literature (Rouzbeh, 1997: 67). Whatever, it happened gradually and during a specific time.

In this time, despite some insisted in changing the literature and even composing poems with a nearly new style, which means to use street talks in poems and proses, the poets and writers could not make a new system for poems for two reasons: first, to respect the eternal system of Persian poems which had left metaphors, ironies and similes in public minds; second, not to have social movements in a century and to have paralyzed thoughts of poets and those who are interested in pomes (Shams Langaroodi, 1998: 36). What replaced formal poems were songs and other informal forms of poems (same: 35) some of which can be known as children poems. Zein Al-Abadein, in a formal poetry-reading meeting, says: ... one in the meeting asked, aloud, an addressee: You, Shams Al-Shoara, have you composed any new poem recently? Replied: yes, I wrote something to High Nabob just last night. Tomorrow, Friday, I will order my slave to take it. He took a paper out and started reading. At the end of each couplet, the audiences said bravo repeatedly... Then, he asked me: how was it, Mashhadi? I replied: I did not understand such things at all!! He asked: how? The words are all spiritual. I said: they are not spiritual; such a style is obsolete... no one pays a penny for such pack of lies but in here for reasons of diseases and free times...

Today, there is no hair

The eyebrow's broken 
Deer's eyes are afraid of it

Instead of lip mole

Should say of mineral coal...

Today, whistle of train is heard

Not Andalib Golzar's voice...

(Ebrahim Beik, 1998: 36)

Bottom line purport: to formal poets, the same poets returning from Qajar era, the past literature was like a spring; they assumed that it is the only place from where you can get water; however, spring of the poet in constitutional era was the language and culture of the people involving in the revolution (Shams Langaroodi, 1998: 38). To use devices less in the poems, especially those which had been specifically composed for children, to see excitements of the revolution in poems and to have an increase in common fans of poems are all factors which showed that it was the time to compose poems for children, and the poets do not know sufficient any more just to give some advices to relatives in their works. Constitutional movement, as it was effective in the Persian literature, was a help to children literature. Although some writers and poets, who were familiar with west literature, did not address children, they did not neglect them and some poems have been left by them for the children in elementary schools (Hasheminasab, 1992: 22). In this period, the children poems were composed in classic from as those in previous periods. Some poets such as Iraj Mirza (1873-1925) and Ashraf Al-Din Hosseini (1872-1895), who were of veterans of children poem composers, did their works in the same form. The children poems became simpler and easier to understand. And, some poets appeared whose poems could be said to be composed in modern classic form, most of which can be found in children poems of recent period. There were and are some poets in free poem field, those who showed their poetical talents and composed poems suitable for children. Nima is of such poets.

\section{Classic}

Children literature involves all matters related to the life and gives a help to the children in all aspects; it stretches their imaginations and arouses and develops their innovating powers (Shoarinejad, 1985:29). Iraj Mirza, Ashraf Al-Din Hosseini, Dehkhoda and Parvin Etesami (1907-1941), even if for entertainment, used such characteristics in the classic poets they composed for children. However, when we say of classic poems, we mean those from resulted from ties of emotion and imagination forming with a rhythm (Shafiei Kadkani, 1989: 236). Classic poems are those which are rhythmic, and its rhythm is formed on the basis of the structure whose prosody has been named. The structure of prosody rhythms is on basis of syllables lengths and each hemistich divided into the forms in which the syllables had to be placed; and, existence of the same forms is the difference of syllabic poems and prosodic poems. The syllabic poem is not placed in any form and is composed on basis of the hemistich syllables. In poems, the most important matter is the rhythm. In fact, some believe that the rhythm and music are essential bases of a poem. If the poems enjoy music, they have to have prosodic rhythms, constant rhythms, rhymes and sometimes secret and visible 


\section{Macrothink}

Journal of Sociological Research

ISSN 1948-5468

2012, Vol. 3, No. 2

miracles. An illustration gives a life to poems and removes the inanition. The poets make the very banal matters attractive, especially for the children, by using illustrations. Parvin Etesami, whose poems are full of innovations, are considered as those who has composed her poetries in classic style (old Persian) in stanza form. As a mother and with women emotions, she says of solid inanimate objects, human beings, animals and birds which talk. Dew and drop, cat and dog, sparrow and pigeon, trap and mouse talk with each other from which the children and adults would reach a moral and educational result. In general, most Parvin's poems deal with educational aspects (Arianpour, 2008: 543). Parvin's poems are of classic poems which keep addressees in child ages, even if not to be composed for children. For many years, "Tears of Orphan" are showing off in the books of preliminary schools and the children enjoy it and understand whatever Parvin has illustrated through a poem:

A king passed through a way, one day

Every one cried his happiness away

Among them, asked one orphan child

What is on king's crown bright?

One replied we don't know what it is

Just it is an expensive thing

An old humpback woman went closer and said

It's my tears and your bloods

He's lured us with a clothing and cane of shepherd

This wolf is familiar with the herd

A pious man who buys villages and estates is a bandit

A king who swindles the people is a beggar

Look at tears dropping from orphans' cheeks

To see a real bright of a gem

(Parvin Etesami, 1976: 143)

Poem of "Mother" by Iraj Mirza is another classic one composed in childish style. The poem was available in a book of secondary grade in elementary schools in 1950:

It's said when mother bore me

She taught me how to get the mamma

She sat beside my cradle

And taught me how to sleep

She took my hands and stayed with me leg to leg

So that she taught me how to walk

One and two words on my tongue

She put and taught how to talk

She wore me a smile on my lips

She taught how to bloom

So, my being is of hers

I'll love her until she survives and I do 


\section{Mll Macrothink}

(Iraj Mirza, 1974: 162-163)

Some other classic poems, which can be considered as children poems, are represented as follows:

The goat goes to desert and the kid

Groans for his separation from the mother

He cries baa baa every moment

And remembers his mother with his voice

The goat goes to the desert with shepherd

And eats of plants and running water

So that her mamma will be milch

Then, they will come back home with the herd

The goat runs ahead

To milk her kid

(Habib Yaghmaei, 1950: 83-84)

The poems of Adhraf Al-Din Hosseini, which have been published in "Literary Flower garden", have been also composed in a traditional style and with a simple childish language. Ashraf Al-Din writes in the introduction: "those who hold sciences and knowledge know that one of the tools to educate in new schools is to memorize the poems by which not only the students' memories are refreshed but such poems involve moral matters. They give a very simple moral lesson to the children, which will never be forgotten and stay in memories. Unfortunately, a comprehensive book of rhythmic stories and simple poems has not been available to the school students and they have deprived from such knowledge. Therefore, Ashraf Al-Din Hosseini has arranged the book and dedicated it to educations (Eternal Generalities of Nasim Shomal, 2006: 797).

\section{Modern Classic}

Each poem is an experience and all its components shall conform to the experience. If any part of a poem related to a world, a contradiction might happen and a part might negate the other and the no result might be gotten (Shafiei Kadkani, 2001: 98-99). From constitutional era, children poems grew up. The poets had found out that their works would be known as a literary one for children when it had been written artistically (Hejazi, 2006: 105). Therefore, they tried to create the works better than before; new themes were placed in children poems, simplicity and fluency increased, and they got closer to the children's world. Modern classic poems were not only to educate the children nor to be composed to praise homeland, mother and educations but, in addition to whatever valued for the first childish poems, they were full of childish feelings, plays, sometimes humor, amusements and some songs on nature; however, children literature in our country has sometimes stopped its movements and sometimes has gone ahead, in a good occasion, with even hasty, inadequate, unconsidered and wrong steps, although being involved in social ups and downs like other cultural and social phenomenon (Khosrownejad, 2003: 15). In general, the most important purpose of 


\section{Macrothink}

composing a poem should be to make him/her enjoy. So, the discussion should be looked at from a child's mental view and his/her needs should be considered independently (Jalali, 2010:80). If we consider childish poems of Ashraf Al-Din Hosseini (Nasim Shomal), Laureate Bahar and Parvin Etesami as childish classic poems, anyone who has composed poems for children with rhythms and rhymes in couplets, quatrains, etc. even in the same time of named poets, will be considered as poets who have composed Modern Classic Poems. One of poetical form in Persian is quatrain which is the newest form among of Persian classic poems and got common after constitutional era in Iran. This form has been developed by double-couplets with a coherent meaning with a difference that, contrary to double-couplets, quatrain is not rhymed in first, second and fourth hemistiches; it is just enough to be rhythmic. Quatrain, for its free and various rhymes, has many possibilities for childish songs (She'rdoust, 1979: 229). Therefore, many poets have composed poems with such a form which have been considered as modern classic poems. Of those who have composed with quatrain form, is Mahmoud Kianoush, who is one of first poets for children. After him, many poets selected this poetical form.

\section{I move backward}

I move forward

Come to me, my swing

Go away, my swing

I cry sometimes

I swing sometimes

Either I enjoy clean air

And I do for the sun as well

(Kianoush, 1990: 40)

or:

O! my dear children

My flowers in life garden

My poems readers

In childhood

Will never been

Forgotten your memory

Forever, we'll be together

In Mahmoud Kianoush's poems

(Kianoush, 1991: 58)

or:

Allspice flower filled its smell

Around the room space

The pleasant smell directed my eyes

To the new branches...

(Dowlatabadi, 1998: 291).

Ofcourse, the poets who used quatrain form did some innovations in using the rhymes. They 


\section{Macrothink}

sometimes rhymed the first and third, second and fourth hemistiches or they did the same in the first and fourth, second and third hemistiches until when the quatrain made to be freer in rhyming rules, and rhymes were just observed in the second and fourth hemistiches. And, such a joint quatrain got more common than other forms. Such a poetical form, called general rhymed couplets, is in fact a shortcut between traditional and free style of Nimaei which will be considered (Salajegheh, 2008: 454). It should be said that Laureate Mahmoud khan Bahar, who is called of the first poem composers for children, has a poem in quatrain form which can be said to be partly with childish theme. Late Sirous Tahbaz has quoted the poem in an article:

\section{I went to Lalehzar Park}

I saw three rose-cheeked friends

One as a flower and two as spring

Wearing gilt clothes

(Seyedabadi, 1979: 23)

Some other quatrain poems by children poets in recent years:

My mother sews

My books with hands

How lucky I am, cause

My mother is a seamstress

How smooth and warm this coat is

Its color is blue

No other seamstress

Is better than my mother

(Ghasemnia, 2001: 11)

When the cloud says of you

The yellow willow gets green

When water memorizes poems

Ifeel nostalgic

(Salehi, 1996: 9)

An example of a quatrain in revised form (regular shortening and elongating of hemistiches):

The life's been interpreted

In crickets' chirps

Or on electricity post

Into a crow's eyes...

(Shabannejad, 2003: 2)

Quatrain is the most common form of poems in English which is used with different rhythms and rhymes. Most of Mahmoud Kianoush's poems which are in quatrain form are due to his acquaintance with English. The following poem is another example of a quatrain by Parvin Dowlatabadi:

Snow's fell, snow fell

Shall make a fire

Snow's fell, snow fell 


\section{Mll Macrothink}

Shall wear clothes

Dead branches of trees

Is full of white snows

Snow flowers can be

Picked from the branches...

(Dowlatabadi, 1998: 282).

\section{Free Poem}

Talking of free poems, Nima Youshij (1897-1959) is remembered, who is called "father of Persian free poem". Nima was a pioneer in a new way in the history of contemporary Persian poems. Although there were some others who gave a help to free poem, before Nima, and used free themes in their poems, he was more successful in selecting his themes of the nature and people and for his purpose, in prosodic rhythms and using rhymes, he did some manipulations differing from common styles in traditional poems. Nima's view on changing the Persian poems is as follows: "The literature should be changed in all aspects. A new subject is not enough nor to extend a theme and to state it in a new way. Not it is sufficient to move the rhymes nor to add or remove the hemistiches or other things. We have to create a new form; the way has to be changed and compose a poem of descriptive and reliable models which are available in the intelligent world of human beings (Arianpour, 2008: 619). Nima's innovation, manipulations in the rhythms of Persian poems, was an improved form of the old poems. By this from, he composed poems for the children since Nima form is of the best forms for children poems; a form which can be learnt, easily, by children for its short rhythms and constant rhymes (Ala', 2003: 117). The free poem got so popularity in 1970s and 1980s that tradition oriented poets were influenced, contrary to their essences. Some confirmed the free poems conservatively and some gradually started to compose free poems (Rouzbeh, 2002: 90). However, what is obvious is that horizons of today poems for children can be seen in Nima's poems. Of his style in composing poems for children is to use short stanzas, which fits the poetic capacity of children more and closer. The following poem is of his childish poems:

O! children ... spring

Buds opened

Snows melted

From grasses

From mountains

O! children ... spring

(Nima, 1971: 1)

And:

A crow in a garden

Has a nest

On a branch of a tree

Ouch, ouch

A sparrow, too 


\section{$\triangle$ Macrothink}

Has a nest

Ouch, ouch

(the same: 4)

Of course, frequency of the composed poems, especially successful poems in this form, is low. The following poem is another example of Nimaei:

A lily flower cries, from greenhouse, come back

I cannot breathe here

My heart will die, my heart

Mirror's become as thin as the heart

With breath voice, windows break

Break without any voice

Behind glasses of the greenhouse, my thin heart

Wants a garden and all sounds

It wants all and all

(Sha'bannejad, 2003: 20).

\section{Conclusion}

From the beginning of composing poems for children, purposes of the poets have been either to educate them or they wanted to impose their own social and political purposes in poems to children and each of them has composed his/her poems in a national, religious national or religious space. In compositions whose origins are sometimes the national belief, the poet employs national myths, heroes, ancient and mythological stories, mostly Iranian characters in Persian literature masterpiece, Shahnameh, in his/her poem. And, sometimes, religious national beliefs and religious epics form themes of Iranian children poems, and sometimes both. Therefore, intellectual tendencies of children poets are divided in three categories: national tendencies, religious, and religious national. In addition, the poets have composed their poems in classic, modern classic and free forms in different times among which the modern classic, especially in quatrain form, has satisfied the children poets. To reach a conclusion, we can say, considering a change in the society structures and Iranian traditional society moves to a modernity, children poets have tended more to new and modern themes which influence new needs of the present century; and, one the reason might be literacy and knowledge in Iranian families and Iranian children's needs to the modern world, the world that acquaintance with its societies values and traditions helps to develop and keep coexistence spirits and to tolerate different, and sometimes opposite, thoughts. Considering different cultures in Iran, the Iranian have had a wide look at other cultures and religions and lived beside other cultures in peace during the history. This is shown in most poems by children poets.

\section{References}

Institute

1995, "Children in the World", Tehran, Intellectual Development of Children 
Ala', Afshin, 1998, "Breeze of Wind's Daughter", Tehran, Banafsheh.

Alipour, Manouchehr, 2000, "To Analyze \& Criticize Children Poems", Tehran, Tirgan.

Arianpourm, Yahya, 2003, "From Saba to Nima" (in 2 volumes), Tehran, Zavar Publications, $8^{\text {th }}$ edition.

Dehghan Azad, Morteza, 1998, "Butterflies Whispers", Tehran, Tarbiat Co

Dehkhoda, Ali Akbar, 1982,"Divan" Tehran, Sokhan

Dowlatabadi, Parvin, 1998, "On Cloud Boat", Shiraz, Rahgosha, $2^{\text {nd }}$ edtion

Gilani, Seyed Ashraf Al-Din, 2006, "Eternal Generalities of Nasim Shomal", with efforts of Hossein Namini, Tehran, Asatir

Hejazi, Banafsheh, 2006, "Children Literature, Characteristics and Aspects", Tehran, Roshangaran.

Iraj Mirza, Jalal Al-Molk, 1974, "Divan", with efforts by: Dr. M.J. Mahjoob, Tehran, Bina. Jalali, Maryam, "Prosodic Rhythms in Children Poems", in "Children Moon", $14^{\text {th }}$ year, No. 3 (Jan. 2011): 79.

Khosrownejad, Morteza, 2003, "Innocence and Experience - an approach to the philosophy of children literature", Tehran.

Kianoush, Mahmoud, 1990, "Green Indian Parrot", Tehran, Intellectual Development of Children Institute

Nazar Ahari, Erfan, 1997, "Behind Cloud Alleys", Tehran, Neyestan

Poornamdarian, Taghi, 1998, "my house is cloudy - Nima's poem from traditions to modernity", Tehran, Soroush

Salajegheh, Parvin, 2008, "From the Eastern Garden - theories on children poems criticism", Tehran, Intellectual Development of Children Institute.

Seyed Abadi, Ali Asghar, 2001, "Poems in Margin - a study on children poems", Tehran, Vijeh Nashr.

Sha'bannejad, Afsaneh, 2003, "Song Glass", Tehran, Intellectual Development of Children Institute.

Shafiei Kadkani, Mohammad Reza, 1980, "Periods of Persian Poems - from constitutional era to monarchy fall", Tehran, Toos

Shams Langaroodi, Mohammad, 1991, "Analytical History of Free Poems", Tehran, Center Company. 
She'rdoust, Ali Asghar, 1997, "Landscape of Contemporary Poems of Afghanistan", Tehran, Bina

Shoarinejad, Ali Akbar, 1985, "Children Literature", Tehran, Bina

Yamini Sharif, Abbas, 1966, "Angels' Songs", Tehran, Golden Books organization subordinate to Amir Kabir Publications 